\title{
Engagement in Translation: Interactional Metadiscourse Markers in American Presidential Debates
}

\author{
Mohammed Farghal \\ Department of English, Yarmouk University, Jordan \\ Bushra Kalakh \\ Departmentof English, Gulf University, Kuwait
}

Received on: 5-9-2019

Accepted on: 27-11-2019

\begin{abstract}
With an audience in mind, politicians draw a political persona whereby their speech is engineered to involve receivers in a promised future. From their vocabulary arsenal, they choose words and structures that maintain a deliberately devised stream of thoughts to urge the electorate to vote. Based on a large corpus, this paper examines a selected number of engaging English expressions including (listener) pronouns, appeals to shared knowledge, directives, questions, and personal asides in order to firstly understand how they function metadiscursively in American presidential debates and, secondly, how they lend themselves to translation into Arabic. The analysis is based on Hyland's (2005) model of metadiscourse markers and Wieczorek's (2013) Clusivity in political discourse, with an eye to Nord's (2007) concept of metacommunication in translation. The findings indicate that omissions and misinterpretations of subtle engagement markers that speak to an audience can disturb the metadiscursive channel as they may shift focus and miscommunicate the messages in terms of the phatic and persuasive functions. In particular, the fact that, unlike English, Arabic is a highly inflectional language, and still lacks research models of metadiscourse markers, places an extra burden on translators between English and Arabic in this sensitive area.
\end{abstract}

Keywords: English, Arabic, translation, metadiscourse, clusivity, political debates.

\section{Introduction}

Since its coinage by Zellig Harris in 1959, the term 'metadiscourse' (MD) has been the subject of numerous studies in different fields. Translation Studies (TS), as a relevant field, has stepped widely into covering various issues confronting language mediators with special attention given lately to how or in what vessel a message is communicated rather than to simply look at the propositional content of utterances. In academia, there is primary discourse (facts or informative language) and secondary discourse that aids in understanding primary discourse (Sultan 2011). More precisely, discourse is embodied in the words and expressions that impart propositions, while MD is an expression method that guides social bonding occurring between speakers and their audience. To Hyland $(2015,1)$, it is "the author's rhetorical manifestation in the text, an intervention to refer to the discourse organization and the expressive implications of what is being talked about". Thus, to metadiscourse or interact interpersonally, a speaker appears in dialogue with a personality, an attitude and shared assumptions.

${ }^{\circ} 2020$ JJMLL Publishers/Yarmouk University. All Rights Reserved. 
In the embryonic stage of MD, Jackobson (1960/1985, 114) discusses the metafunctions of language in order to emphasize their capacity "to explain, gloss, comment on, predicate about or refer to" the verbal code itself. In relation to translation, Holmes (1972) calls for a meta-discussion in TS whereby an integrative approach to theoretical and applied studies that agrees clearly upon terminology and describes language per se is adopted. The prefix meta- is used to denote studies that focus on linguistic items that describe language in action aside from its informative task, or as language or communication about or dealing with the linguistic code itself (Bublitz and Hübler 2007). Metadiscourse has evolved over time to embrace variable terms such as 'signaling' (Meyer, 1975), 'metatalk' (Schiffrin, 1980) or 'text reflexivity' (Mauranen, 1993).

\subsection{Definitions of metadiscourse}

Harris (1959, cited in Hyland 2005, 3) defines MD as "a way of understanding language in use, representing a writer's or speaker's attempts to guide a receiver's perception of a text”. Whether through a non-propositional or an interpersonal perspective, most scholars have agreed upon the fact that MD is discourse about the ongoing discourse. In other words, it carries the social aspect of speech whereby a text producer reaches out to whoever is receiving the discourse. Therefore, Hyland $(2005,39)$ considers $\mathrm{MD}$ as "the means by which propositional content is made coherent, intelligible, and persuasive to a particular audience" for the purpose of handling "interpretive processes as opposed to statements relating to the world". This approach is an integrative or a broad approach, while Mauranen's (2010) and Ädel's $(2006,2010)$ is described as a non-integrative or a thin approach.

On the one hand, Hyland $(2005,37)$ stresses the internal nature of MD whereby its markers are used as self-expressions "to negotiate interactional meanings in a text, assisting the writer or speaker to express a viewpoint and engage with readers as members of a particular community". In this way, a writer-reader or speaker-listener relationship is being developed to reach the purposes of communication. MD markers also augment arguments related to the unfolding discourse by referring to world experiences.

On the other hand, the non-integrative, thin approach parallels MD to discourse reflexivity including "discourse elements that incorporate interactive and discourse-organizing functions" (Mauranen 2010, 17). Such elements, Mauranen (p. 16) argues, have two main tasks, namely "sharing experience and negotiating interaction". Thus, interlocutors benefit from language reflexivity as it facilitates communication through providing a setting that helps them relate to the ongoing discourse. For his part, Ädel (2006) views reflexivity as an umbrella term that enfolds MD and intertextuality. Within this model, Ädel $(2010,75)$ defines the former as "reflexive linguistic expressions referring to the evolving discourse itself or its linguistic form, including references to the writer-speaker qua writer-speaker and the (imagined or actual) audience qua audience of the current discourse". In this way, MD instances act on one of the three 'components of the speech event', viz. the text/code, the writer, or the reader.

As can be seen, MD is defined through different lenses by shedding light on discourse about ongoing discourse. Discrepancies in theory have yielded a number of taxonomies in order to understand what MD serves in language exchange. This paper adopts Hyland's (2005) interpersonal model of MD. 
Engagement in Translation: Interactional Metadiscourse

Markers in American Presidential Debates

1.1.1 An interpersonal model of MD (Hyland 2005)

Hyland's (2005) model of MD is built on his earlier models (1998, 2000), and on Thompson's (2001) terminology which acknowledges an interactive as well as an interactional level, including stance and engagement resources (Table 1).

Table1: An interpersonal model of MD (Hyland 2005)

\begin{tabular}{|c|c|c|}
\hline Category & Function & Examples \\
\hline Interactive & Help to guide the reader through the text & Resources \\
\hline Transitions & express relations between main clauses & $\begin{array}{l}\text { in addition; but; thus; } \\
\text { and }\end{array}$ \\
\hline Frame markers & refer to discourse acts, sequences or stages & $\begin{array}{l}\text { finally; to conclude; } \\
\text { my purpose is }\end{array}$ \\
\hline $\begin{array}{l}\text { Endophoric } \\
\text { markers }\end{array}$ & refer to information in other parts of the text & $\begin{array}{l}\text { noted above; see Fig; } \\
\text { in section } 2\end{array}$ \\
\hline Evidentials & refer to information from other texts & $\begin{array}{l}\text { according to } \mathrm{X} ; \mathrm{Z} \\
\text { states; }\end{array}$ \\
\hline Code glosses & elaborate propositional meanings & $\begin{array}{l}\text { namely; e.g.; such as; } \\
\text { in other words }\end{array}$ \\
\hline Interactional & Involve the reader in the text & Resources \\
\hline Hedges & withhold commitment and open dialogue & $\begin{array}{l}\text { might; perhaps; } \\
\text { possible; about }\end{array}$ \\
\hline Boosters & emphasize certainty or close dialogue & $\begin{array}{l}\text { in fact; definitely; it is } \\
\text { clear that; }\end{array}$ \\
\hline Attitude markers & express writer's attitude to proposition & $\begin{array}{l}\text { unfortunately; I agree; } \\
\text { surprisingly }\end{array}$ \\
\hline Self mentions & explicit reference to author(s) & I; we; my; me; our \\
\hline $\begin{array}{l}\text { Engagement } \\
\text { markers }\end{array}$ & explicitly build relationship with reader & $\begin{array}{l}\text { consider; note; you can } \\
\text { see that }\end{array}$ \\
\hline
\end{tabular}

On the one hand, interactive MD markers are reader/listener-guiding features that customize discourse to its audience according to their prior knowledge and in line with the producer's desired outcome. These resources walk the reader/listener towards the writer's/speaker's 'preferred interpretations' (Hyland and Tse 2004, 168). On the other hand, interactional markers reflect the interaction's dialogic nature. In other words, text producers express their "textual voice" by evaluating their judgments, engaging their audience while showing solidarity, expecting objections, and responding to them in a dialogue (Hyland 2005, 50). Put simply, interactive markers perfect the text by making it reader-friendly, while interactional markers stretch the producer's arms to receivers to portray his/her presence, attitude towards, commitment to or detachment from an argument.

\subsection{The translation of $M D$}

In TS, the term MD rarely appears despite the continuously growing body of research on discourse markers in different genres and through various perspectives. Translation as a product that needs to 
observe such markers for their communicative power and contribution to the overall coherence of a text within a context has not been satisfactorily studied. One of the few voices concerned with this aspect of translation is Nord $(2007,127)$, who suggests a translation-relevant text analysis where four functions of communication are included, i.e. the referential or representative, the expressive or emotive, the appellative or operative, and the phatic function (cf. Jakobson 1960, Bühler 2011). To Nord, metacommunication, which is distinct from object communication, is another name for MD or language reflexivity; it means (p. 172):

The sum total of verbal and nonverbal (including paraverbal) means used by a writer or speaker to comment on the conditions and factors of the communicative occurrence in progress, including the interacting partners (author and audience) and the relationship holding between them.

Nord's definition, as can be noted, covers the phatic function that activates the sender-receiver communicative channel by starting, continuing or ending contact. Hence, the metalanguage that "refers to the communicative event in progress" can be considered part of the phatic function (Nord 2007, 173; cf. Jakobson 1960). Moreover, Nord points out that this kind of communication is conventionalized to the extent that its markers are used and identified "in the course of acquiring communicative competence". Therefore, she recommends that translators should be aware of how such markers function in their mother language before translating them into another. She (p. 171) also proposes a systematic approach for the professional translation of metacommunication by describing its conventions.

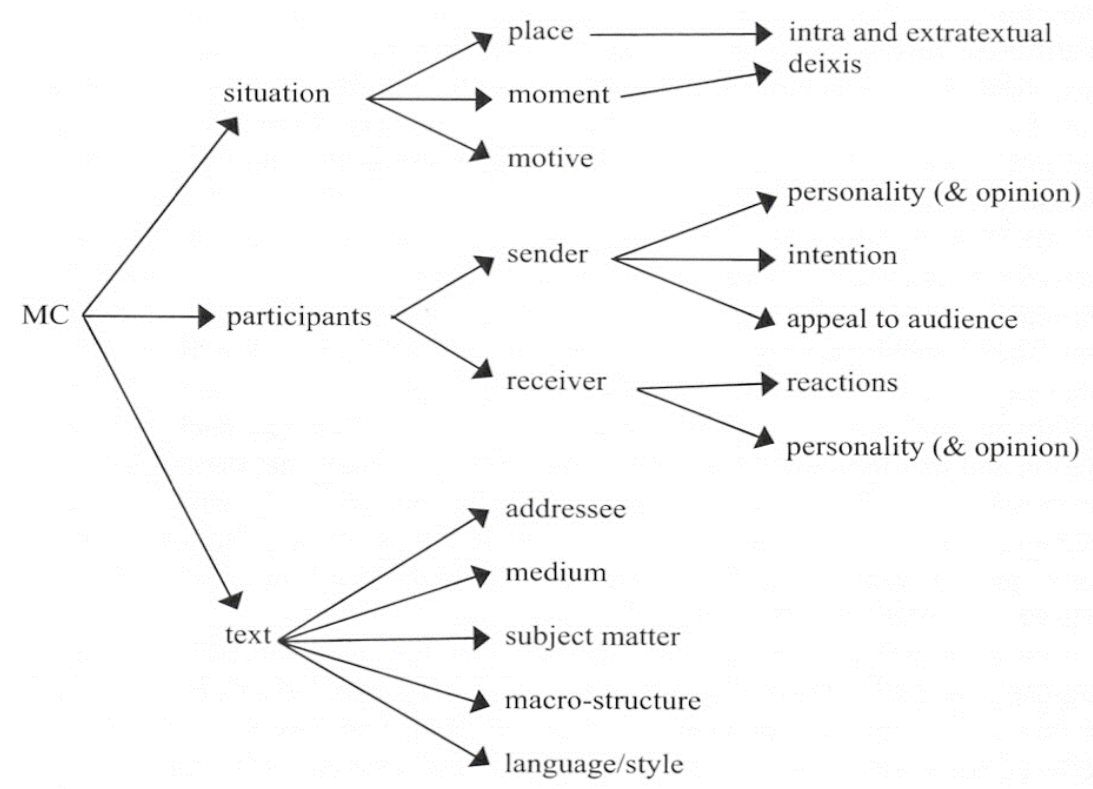

Figure 1: Reference objects of metacommunication (Nord, 2007)

In figure 1 above, attending to the metacommunicative aspect when translating texts requires the observation of elements like the situation, which involves where, when and why communication is 
Engagement in Translation: Interactional Metadiscourse

Markers in American Presidential Debates

happening. Besides, language mirrors the participants' intention, personality and appeal to audience, along with both extra- and intra-textual features (Nord 2007, 176-7). This model includes the phatic function as a translation function indicating "the culture-specificity of the metacommunicative behaviour" (p. 183). Therefore, translators need to be trained to predict different meaning levels and to adapt MD utterances to fit within the target culture's conventions in order to appropriately reach the targeted addressee (see also Wang and Fang 2015).

\subsection{The translation of MD in politics}

With MD being a reflection of its users' rhetorical and pragmatic choices, it becomes essential that political translation pay attention to it. Indeed, as Schäffner $(2012,104)$ puts it, "language is a social phenomenon" that is interwoven with political actions, thereby the study of Political Linguistics has emerged. It inspects the language of politics and the politics of language by means of various analytical methodologies. Political talk needs to be contextualized within political events that feature "structural properties of text or talk itself" (Van Dijk 1997, 15). Political discourse analysis, consequently, caters for the structure of speech, who speaks to whom, about what, and in what manner within concerned communities. In political battles, rhetoric becomes part of discursive persuasion that is necessary to secure victory in politics. Acknowledged by Aristotle as the art of persuasion (cited in Hyland 2005, 64), there are three persuasive means of rhetoric: ethos, pathos and logos. They work together to persuade an audience; ethos relates to the credibility or reputation of the addressor built up in the course of communication, pathos represents the affective appeal to the addressees, and logos embodies the characteristics of the speech itself.

It is important to note that since the early building of modern democracies, talk in politics has attracted the attention for analysis and study because of its weight in shaping today's political world map. Political talk provides dynamism that enables the speaker to influence people through affordances that are absent in the written modality of language. This includes the chance to underscore metadiscursive means via tone, intonation, pauses, facial expressions, body position, or hand gestures (Kintsch 1998). Furthermore, speech fosters involvement, where ideas may appear in strings with connectives or coordinating conjunctions being missing. Speakers can refer to themselves or to listeners using pronouns like "I, we, us or you", and mental processes expressed explicitly using expressions like "I thought ..." or "I had no idea" (Chafe 1982:46). In addition, a speaker can monitor informational flow by using phrases like I mean, you know, well, which abide by the Phatic Maxim, i.e. “Avoid silence!” (Leech, 1983). $\mathrm{He} /$ she can regularly emphasize speech by particles like "just" or "really" to obtain more audience engagement and can employ direct quotes to underline or authenticate what is being said (Latawiec 2012, 11).

Analysis of talk in the world of politics would require a framework that revolves around analyzing strategies in political discourse. The term clusivity is used to describe the pragmatic and cognitive aspects of "association and dissociation encoded via language and engendered in political discourse" (Wieczorek 2013 , 29). In presidential debates, for example, the term will be occasionally used to refer to "a number of 
linguistic means by which the speaker communicates (the lack of) belongingness of chosen elements in a particular speech situation" (p. 28). Put differently, candidates' speech comprises a number of techniques they employ while presenting their plans, defending their opinions on controversial issues, arguing with the other parties over conflicting terms, and refuting claims, among others. These techniques join forces to serve nominees' ultimate objectives and help them in directing the electorate's views toward a certain sought decision.

Wieczorek $(2013,213)$ further proposes a trifold model called the Perspective-DistanciationProximization model. The first component represents point-of-view operations that involve shifts in perspective that allow one discourse entity (e.g. speaker) to change the spatial, temporal and/or axiological position. Distanciation emanates from conceptualizing groups as "us-good" and "them-bad", thus helping candidates to secure distance between themselves and the other "through negative otherpresentation or enhancement of other's non-inclusive status". For its part, proximization helps in consolidating more unity and closeness by conceptually approaching the in-group through reflecting a positive self-image and common ground. Some of the concepts that clusivity in politics involves are "ideological polarization, positive self-presentation, negative other-presentation, emphasizing power of the self, and discrediting the other" (p. 29). Such concepts clearly intersect with metadiscourse as they help in explaining the political motives behind encoding interlocutors' speech for a persuasive end.

With the concept of clusivity in political discourse, it becomes the responsibility for translators to remain aware of the triadic nature of their job as mediators between speakers and their addressees. As they re-contextualize across languages, cultures and discourse domains (Schäffner 2012, 103), an effort to interpret implicit meaning needs to be exerted since speech in politics is closely connected to culture, which is the container that embodies the practice of politics in a given society (Chilton and Schäffner 2002, 8). Another influencing factor on political discourse is ideology, which makes translation a selective act. That is, political institutions dictate the choice of translated texts in order to serve their policy that enhances or deforms the public image of a candidate. Mirroring such ideologies means investing in language and language itself is "a material form of ideology" (Fairclough 1995, 73). Inevitably, translational manipulation occurs including quantitative management of the ST, structure reorganization, message transformation, or supplementation (such as shifts between active and passive voice or the addition of contextualizing information). Such steps reflect the role played by ideology in translation (Schäffner 2010, 273). In sum, this scheme eliminates the possibility of viewing the translation of political discourse, which in many cases is media translation, in terms of the linguistic equivalence it achieves. Rather, it needs to be viewed as an aftermath of confronting language, culture and ideology barriers.

\section{Objective and Material}

The objective of this study is to examine how engagement markers in metadiscourse are translated in political dialogues. The material consists of three US 2016 political debates: three presidential debates and one vice-presidential debate. The sample is closely examined for phrasal representations in 
Engagement in Translation: Interactional Metadiscourse

Markers in American Presidential Debates

interactional metadiscourse, including listener pronouns, appeals for shared knowledge, directives, questions, and personal asides (Hyland 2005). The political weight of these interactional markers is studied using Wieczorek's (2013) concept of Clusivity in political discourse. An appeal is also made to Nord's (2007) conception of the functions of translation. For ease of reference, each example taken from a debate will be labelled as either FPD (first presidential debate), SPD (second presidential debate), TPD (third presidential debate), or VPD (vice-presidential debate).

\section{Discussion}

The four debates comprise 65,738 words, while their Arabic counterparts comprise 54,340 words. The percentage of engagement markers is $43,7 \%$ among other MD markers. This testifies to the nature of the genre of political dialogues since audience inclusion markers, which usually accompany selfpresentation, serve politicians more than argument strengthening markers, hesitation expressions, or refutations. The Table below shows the most frequent markers within the engagement category and their Arabic translations. As can be seen, pronouns top the list with a percentage of $77.6 \%$ in engagement markers.

Table 2: Most frequent engagement markers.

\begin{tabular}{|c|c|c|c|}
\hline Marker & occurrences & $\%$ in this category & Translations \\
\hline You & 1,184 & $36.5 \%$ & أنتَ/ أنتِ/ أنتما/ أنتم/ كَ/ كِ \\
\hline inclusive-we & 785 & $24.2 \%$ & نحن/ نا \\
\hline inclusive-our & 359 & $11.1 \%$ & نَا/ لدينا/ - \\
\hline Your & 188 & $5.8 \%$ & $s / s$ \\
\hline have to & 118 & $3.6 \%$ & علينا/ يجب/ لابد / - \\
\hline Total & 2,954 & $77.6 \%$ & \\
\hline
\end{tabular}

\subsection{Engagement markers}

According to Hyland $(2005,54)$, engagement markers perform two main functions: to address the receivers of a piece of discourse by acknowledging their presence and to involve them rhetorically through interaction that pulls them in when needed, anticipates their reaction, and leads them to a conclusion. With presidential debates targeting an electorate, this becomes an essential game-changing tool with which politicians enhance the ethos and manage the communicative channel, promoting their self-image or arguing against the other candidate to maintain communication with them and persuade them to vote in their favor. Politicians, in this way, perform the appellative function that aims to attain a certain response from the audience by means of persuasion (Nord 2016, 9).

In Hyland's interpersonal model of MD (2005), engagement markers are of several types: reader (or listener) pronouns, appeals to shared knowledge, directives, questions, and personal asides. Each of them is illustrated below with examples from the corpus. Since these types mostly exist in cluster form, Table 3 below shows a sample of the most frequent expressions of engagement. The following discussion examines these expressions from a translational perspective. 
Farghal, Kalakh

Table 3: A sample of most frequent phrasal engagement markers.

\begin{tabular}{ccc}
\hline marker & occurrences & \% in this category \\
our country & 95 & $2.9 \%$ \\
you have to & 92 & $2.83 \%$ \\
we have to & 91 & $2.8 \%$ \\
(you) look at & 90 & $2.77 \%$ \\
you know & 85 & $2.62 \%$ \\
let me & 60 & $1.85 \%$ \\
tell you & 54 & $1.66 \%$ \\
we need to & 39 & $1.2 \%$ \\
(you) go to & 31 & $0.96 \%$ \\
we should & 26 & $0.80 \%$ \\
\hline
\end{tabular}

\subsubsection{Listener pronouns}

In politics, pronouns are not to be dealt with casually since they "can be used to induce interpreters to conceptualize group identity, coalitions, parties and the like, either as insiders or as outsiders" (Chilton and Schäffner 2002, 30). When translating from English into Arabic, the English second person pronoun you bears a degree of ambivalence that stems from the absence of gender and number. Arabic uses different pronoun forms based on gender and number in the second person pronoun, viz. the singular أنت أنت ['anta], the singular feminine أنت ['anti], the dual masculine and feminine, أنتما ['antumaa], the plural masculine, أنتم ['antum], and the plural feminine, أنتن ['antunna] (A list of Arabic phonetic symbols is given in the Appendix). This requires more effort on the part of the translator to determine the gender and number of the addressee(s). The following example shows audience inclusion by the speaker: (A back-translation of Arabic renderings is given between square brackets)

(1) So you've got to ask yourself, why won't he release his tax returns? (FPD)

$$
\text { لذلك يجب أن تسألوا أنفسكم ، لماذا لا يكثف عن عائدات الضرائب خاصته؟ }
$$

[So you must ask yourselves why he doesn't release his tax returns]

As Hillary Clinton approaches the audience to highlight her opponent's ill doing, she involves listeners using the pronouns you and yourself. The translation relays the second, but blurs the first. Using the modal verb yajibu يجب [must], which is not marked for gender in Arabic, to render you've got distances the speaker from the audience, viz. what is double marked and engages addressee pronouns in English is unjustifiably reduced to one instance in the Arabic rendering. To achieve a comparable metadiscursive impact, the use of the modal expression 'alay-kum عليكم [on you (PL/MAS)] caters for the effective inclusion of all American people and alerts them to the decision that lies ahead of them in these elections. The translator, however, has done well by rendering the singular reflexive pronoun yourself, which is used rhetorically to include all American people, into the unmarked masculine plural reflexive pronoun 'anfusa-kum أنفسكم [selves-your (PL] rather than the unmarked singular reflexive pronoun nafsaka نفسك [self-your (SG/MAS)]. Addressing the audience using the masculine singular pronoun in Arabic would sound unnatural, viz. يجب عليك أن تسأل نفسك لماذا لا يكثف عن عائدات الضرائب خاصته [you (SG/MAS) 
Engagement in Translation: Interactional Metadiscourse

Markers in American Presidential Debates

must ask yourself (SG/MS) why he doesn't release his taxes returns]. This would fit only when the speaker is addressing a male person, e.g. when Clinton is addressing Trump.

By contrast, the second person pronoun requires a higher degree of sensitivity as it could mean one particular addressee, as can be shown in (2) below:

(2) And if we could run our country the way I've run my company, we would have a country that you would be so proud of, you would even be proud of it. (TPD)

$$
\text { ولو أنه كان باستطاعتنا إدارة الدولة بنفس الطريقة التي أدرت بها شركتي لكان عندنا دولة تفتخرين بها، ولافتخرت بها. }
$$

[If we could manage the country the same way I managed my company, we would have a country you (SG/FEM) would be proud of, and you (SG/FEM) would be proud of it]

By using the singular feminine pronoun in Arabic to render you in both instances, the TT has given the false impression that the addressee is the same in both cases. As a matter of fact, employing the inclusive-we and our in the first clause tells us that the first you refers to the American people, while the second is intended to face the other debater (Clinton) to assert that his discretion in business would even make his rivals proud of his management. This is rhetorically signaled by the use of the intensifying/contrastive adverb even, which claims that Clinton herself would be impressed by Trump's skill in management. This metadiscursive mishap in the Arabic rendering has produced a coherence problem by redundantly interpreting you as referring to the same addressee. It is therefore important that the TT pluralize the first you and singularize the second one, in addition to rendering the inclusive pronoun in our (country), which enhances the metadiscourse in the utterance and engages all American people. Below is an Arabic rendering that caters for both points:

ولنو أنه كان باستطاعتنا إدارة دولتنا بالطريقة نفسها التي أدرتُ بها شركتي لكان عندنا دولة تفتخرون بها حقاً، ولافتخرتٍ حتى

[And if we could run our country in the same way I ran my company, we would have a country you (PL/MAS) would be proud of, and even you (SG/FEM) would be proud of].

أنت Note that the use of hattaa [even] necessitates the presence of an explicit second person 'anti [you (SG/FEM) whose FEM feature is already found in the preceding verb, i.e. the genitive case marker $i$ in laftaxarti لافتخرت [would be proud you (SG/FEM)]. Hence, the Arabic rendering is doubly marked by engaging pronouns due to the presence of the contrastive discourse marker even. Without even, only the verb will be marked for second person, viz. لافتخرت بها [would be proud (SG/FEM)].

First person plural pronouns such as we and $u s$ are another frequent feature in the ST. Such pronouns remain unclear in terms of their inclusiveness as it is the choice of the politician whether to build unison with the electorate by including or excluding them in order to reassure them that they and their party are reliable to serve them. Strategically, "the choice between them is tied in with relationships of power and solidarity" (Fairclough 1995, 127). After a contextual analysis of these pronouns, it is found that they are 
mostly used in their inclusive sense, exemplified by 785 times of we, 359 times of our and 90 times of $u s$. To render them into Arabic, translators need to pay attention to the context to position themselves in or out of dialogue since using we, for instance, inclusively associates the candidate to the people whom he/she views himself/herself as belonging to, thus enfolding them in a sense of rapport and attachment. For example, Clinton employs the pronoun $u s$, we and the phrase our country in the example below to alienate herself from what Trump advocates:

(3) That's who Donald is. I think it's really up to all of $u$ s to demonstrate who we are and who our country is,... (TPD)

$$
\text { هذا هو دونالد . أعتقد حقا أن الأمر راجع لنا جميعا لإظهار هويتنا وهوية وطننا.... }
$$

[That's Donald. I really believe that (it is) up to all of us to show our identity and the identity of our homeland]

With the American nation participating in change, Clinton's use of $u s$, we and our gives a communal sense. The above segment was preceded by incidents where Trump had mistreated some people, thus implying to voters that he was out of the equation Clinton was describing for a better country. The translation has presented the plurality of decision by using the enclitic plural subject pronoun naa 'we' suffixed in the first case to a preposition lanaa لنا [identity-our] and wațani-naa وطننا in the next two instances, respectively. Apart from the impact of metadiscursive employment of pronouns, this conforms to the pronouns profiles of English and Arabic where English subject pronouns must surface in discourse, whereas their Arabic counterparts are suppressed by being incorporated as clitics attached to different lexemes and can only occur separately in emphatic contexts (Farghal 2018). The translator has mitigated the force of metadiscourse in the above example by failing to employ the Arabic emphatic first person pronoun naḥnu [we] and the emphatic third person pronoun hiya هي 'she' as corresponding to the subject pronoun we and a null position in the ST, respectively. Firstly, he has lexicalized the pronoun nahnu by the common noun hawiyyah [identity] and suffixed the first person plural enclitic naa to it. Secondly, he has failed to call up the emphatic pronoun hiya in the next phrase while maintaining the lexicalization strategy and the clitic pronoun, viz.[the identity of our country]. To remedy this serious metacommunicative mishap, two emphatic Arabic subject pronouns nahnu and hiya need to be employed, as can be witnessed in the rendering below: (The emphatic pronouns are highlighted in boldface)

$$
\text { هذا هو دونالد . أعتقد حقا أن الأمر راجع لنا جميعا لإظهار من نحن ومن هي دولتنا... }
$$

[That's Donald. I really believe that (it is) up to all of us to show who we (are) and who (*she) our country (is)] 
Engagement in Translation: Interactional Metadiscourse

Markers in American Presidential Debates

\subsubsection{Appeals to shared knowledge}

For the purpose of affinity, politically targeted people are drawn into an ongoing discussion that relates to their experience. An example of shared-knowledge-appeals is the phrase you know, which is used to either state a commonly-known reality or ask about something to call for attention. With the audience being present in place, Ädel (2010) explains that this phrase aids in managing the communicative channel in spoken discourse. You collocates with know 85 times in the corpus and they appear where there is an intersection of interest between the debaters and their audience, or when delivering new information. If speakers have kept people's knowledge and values in mind, then automatically, translators should "take the target-audience's sensitivity, knowledge, values or even secret desires into account" (Nord 2016, 9). Example (4) and (5) below are illustrative:

(4) But I want to, on behalf of myself, and I think on behalf of a majority of the American people say that, you know, our word is good. (FPD)

$$
\text { لكني أعتقد، عن نفسي وعن أكثرية الأمريكيين، أن الناس يقولون، كما تعله، كلمتنا جيدة. }
$$

[But I believe, on my behalf and behalf of a majority of the Americans, that people say, as you(SG/MAS) know, our word (is) good]

(5) I'm just ... um amazed that he seems to think the Iraqi government and our allies and everybody else launched the attack on Mosul to help me in this election, but that's how Donald thinks, you know, he always is looking for some conspiracy-(TPD)

$$
\text { في الحقيقة أنا مندهشة جدًا، حيث فيما يبدو أنه يعتقد بأن الحكومة العراقية، وحلفائنا والجميع قد شاركوا وشرعوا في هذا }
$$

[In fact I'm very amazed as it seems that he believes that the Iraqi government, our allies and all had participated and started this attack only for the purpose of supporting me in the elections, but in fact this (is) how Donald thinks, as we all know that he always embraces the idea of conspiracy ...]

In (4), the translator has erroneously rendered you know into كما تعلم [as you (SG/MAS) know]. However, the introductory statement shows that Clinton is addressing the American people in general by telling them about an assumingly agreed upon fact, viz. America fulfills her word to her allies. In this way, the translator has damaged the metacommunicative function of the pronoun you by giving the impression that Clinton is appealing to Trump when, in fact, she is establishing a rapport with all American people. Equally serious is the shift of the speaker from Clinton to people, viz. الناس يقولون [people say], although Clinton takes the responsibility of claiming the statement that follows. Below is a rephrased rendering of (4) that captures the metadiscursive function of you know:

$$
\text { لكني أريد أن أقول، نيابة عن نفسي وكما أعتقد نيابة عن أكثرية الأمريكيين، كما تعلمون، إن كلمتنا موثوقة. }
$$


[But I want to say, on my behalf and on behalf of a majority of the Americans, as you (PL/MAS) know, that our word is reliable]

For its part, (5) implies that the speaker, Clinton, has taken the risk of assuming that everyone agrees with what she claims by using you know. However, the translator has substituted the inclusive first person plural pronoun in the expression فجميعنا نعلمر 'we all know' for the measurably inclusive second person plural pronoun you know. While this choice captures the intended meaning generally, it does away with the nuance of appealing to the audience by employing the metadiscursive interjection you know, which appeals to the audience and includes the speaker, but it effectively excludes the debater (Trump) who always bases his arguments on a conspiracy theory. The translation below rephrases (5) more appropriately:

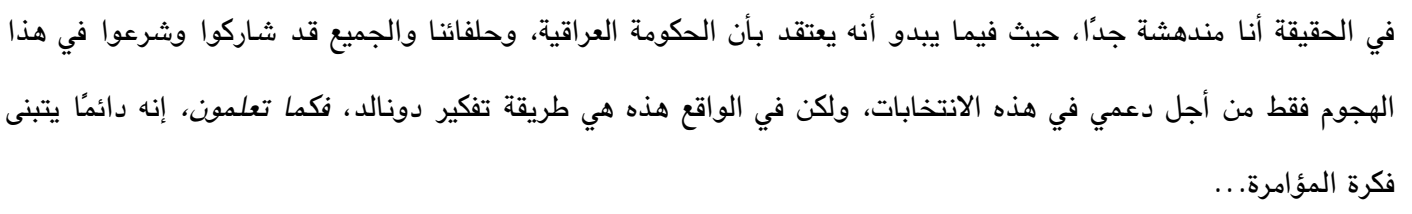

[In fact I'm very amazed as it seems that he believes that the Iraqi government, our allies and all had participated and started this attack only for the purpose of supporting me in the elections, but in fact this (is) how Donald thinks, as you(PL/MAS) know, he always adopts the idea of conspiracy ...]

\subsubsection{Directives}

Hyland $(2005,154)$ defines directives as markers that direct addressees "to perform an action or to see things in a way determined by the addressor". Their function is to manage the message and guide its recipients to what is attention worthy in a power-governed relation (Ädel, 2010). In a direct interaction with the electorate walking them through the speaking candidate's political mind, they are used in the form of imperatives (like see, look, notice, etc.) or obligation modals (like must, should, have to, etc.) that guide those who listen to reach particular conclusions. In their phrasal form, they function in overlap with personal asides (see 3.1.5 below) as in believe me or let me. One of the most frequent directive patterns is have to, occurring 118 times in the ST and instructing people to take action that is textual, physical or cognitive (Hyland 2005, 184-5). As a semi-auxiliary (Greenbaum and Quirk 1990, 62), have to occurs with you 22 times in various contexts. The example in (6) shows how the speaker brings to the awareness of the electorate that it is going to be up to them to decide who will become president, hence opening their eyes to pay closer attention to what concerns them in the personality of their next president.

(6) You have to judge us, who can shoulder the immense, awesome responsibilities of the presidency, (FPD)

$$
\text { وعليكم أن تحكموا على كلينا، من يستطيع تحمل أعباء ومسؤوليات الرئاسة. }
$$

[And you must judge both of us, who can shoulder the burdens and responsibilities of presidency] 
Engagement in Translation: Interactional Metadiscourse Markers in American Presidential Debates

Although the semi-modal auxiliary have to expresses logical necessity in this utterance, the translator employs the deontic modal particle على 'must' which gives a sense of obligation rather than necessity in Arabic. The actual intention has nothing to do with power where the speaker tells the voters about what they are obligated to do; rather, the emphasis is placed on their role as electorate. Thus, the metacommunication here constitutes an appeal to the audience, in which case the translation needs to accentuate clusivity by using the necessity modal marker laabudda لابد to reflect the discursive function epistemically rather than deontically, as below:

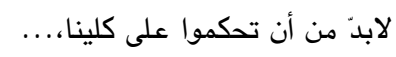

[It's necessary that you judge both of us, ...]

Another example of have to is given in (7) below, where the sense of obligation rather than necessity is intended:

(7) We have to repeal and replace Obamacare. (TPD)

$$
\text { يجب أن نلفي ونستبدل أوباماكير . }
$$

The TT opts for يجب 'must' which captures the obligation sense and marks the verbs نلفي [repeal (we)] and نستبدل [replace (we)] for the inclusive first person plural. One could argue, however, that a double marking by adding the inclusive على attached to the particle would better achieve the appellative function by means of proximizing the nominee to the voters as he tells them that this is a shared responsibility. Hence, the rendering below would better represent the metadiscursive function of have to:

$$
\text { يجب علينا أن نلفي ونستبدل أوباماكير . }
$$

[We must repeal and replace Obamacare/Lit. Must on-us that repeal (we) and replace (we) Obamacare]

Other common directives include let me or let's to guide the listener through an argument to the speaker's claims (Hyland 2005, 154). The ST shows that patterns like let me tell you or let's talk or let's be clear are employed to incite more thoughtfulness using both the imperative phrase and either the personal me or $u s$, and sometimes along with the listener pronoun (you). Interestingly, they appear in the middle of speech to generate more curiosity about the following utterance, similar to what personal asides do to engage, as can be seen in (8) below:

(8) She has been talking about the inner cities for 25 years. Nothing is going to ever happen. Let me tell you, if she is president of the United States, nothing's going to happen. (SPD)

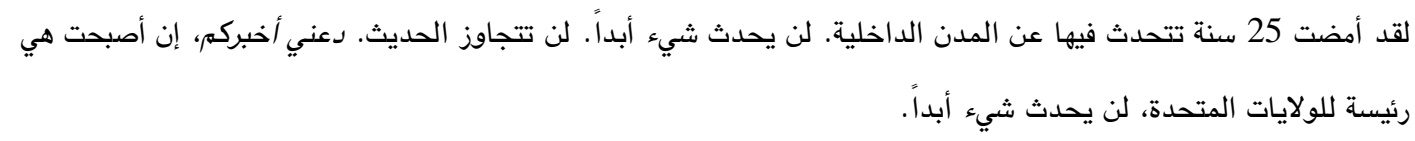

[(She) has spent 25 years talking about the inner cities. Nothing will ever happen. (She) would not go beyond talk. Let me tell you, if she becomes president of the United States, nothing will ever happen] 
One can readily note that the translator is aware of the metadiscursive function of the directive Let me tell you by assigning it to its appropriate place in the Arabic rendering. However, the rendering gives the impression that Trump is addressing an audience through a male person when, in fact, he is addressing all American people rather than one particular male. Therefore, دعني [let me addressing (2ndP/SG/MAS)] needs to be replaced with دعوني [let me addressing (2ndP/PL/MAS \& FEM)]. This linguistic mishap has seriously affected the metacommunicative function of the directive Let me tell you, which should have been rendered into دعني أخبركم rather than دعوني أخبركم, in order to express direct clusivity with the audience rather than address them through an imagined second person singular.

\subsubsection{Questions}

In political debates, questions are posed either by moderators, audience members, or by one debater to the other to keep the conversation going. From a metadiscursive point of view, they embody the phatic function as they establish sender-receiver social contact (Nord 1997:48). Questions may be asked with an expected answer or just rhetorically. The following examples testify to this:

(9) She's been doing this for 30 years. And why hasn't she made the agreements better? The NAFTA agreement is defective. (FPD)

$$
\text { لقد كانت تقوم بعملها لثلاثين سنة، فلماذا لم تجعل الاتفاقية أفضل إذن؟ اتفاقية نافتا متردية، }
$$

[(She) was doing her work for thirty years, so why hasn't (she) made the agreement better then? NAFTA agreement is worsening]

(10) Just like when you ran the State Department, $\$ 6$ billion was missing. How do you miss $\$ 6$ billion? (TPD)

$$
\text { تماما عندما أدرت وزارة الخارجية، حيث اختفت } 6 \text { مليارات دولار ـ كيف تضيعين } 6 \text { مليارات دولار؟ }
$$

[Exactly when she ran the State Department, where 6 billion dollars disappeared. How do you miss 6 billion dollars?]

In (9), we have a generic question that begs an answer from the opponent, and it raises a flag that alerts the electorate to the 30 years she spent in office without any outcome. Apart from the general quality of the rendering, the translator has maintained the metacommunicative function of the question. As for (10), the metadiscourse requires no answer from the other debater or from the audience as the question is structurally interrogative, but has an assertive force (Greenbaum and Quirk 1990, 240). Thus, the rhetorical question implies a negative answer, i.e. this amount of money cannot be missed. The translator has done well by rendering the question rhetorically, thus achieving a comparable degree of its metadiscursive function in the TT by trying to shock the debater and win the audience's approval.

\subsubsection{Personal asides}

While conversing, interlocutors may inject their speech with comments about the ongoing discourse in an acknowledgement of the listeners' presence and as an appeal to them (Hyland 2005, 152). Being 
Engagement in Translation: Interactional Metadiscourse Markers in American Presidential Debates

representations of the phatic function, personal asides work discursively to open, keep open or end the communicative channel (Nord 2007). In the corpus under study, some interjectional statements and exclamatory expressions function as personal asides. Below is an illustrative example:

(11) I assume she had nothing to do with it, but our country is so outplayed by Putin and Assad and, by the way, and by Iran. (TPD)

$$
\text { أفترض أنه لا شأن لها بذلك، لكن تم التفوق على بلدنا على يد بوتين والأسد وإيران بالمناسبة، }
$$

[I assume that (she) has nothing to do with that, but our country has been outplayed by Putin and Assad and Iran by the way]

As can be seen, the personal aside by the way is properly translated into the Arabic personal aside بالمناسبة, which is unjustifiably positioned at the end of the utterance. One may bring up the metacommunicative importance of word order by placing بالمناسبة before the last conjunct rather than after it. The rhetorical weight of this placement affects the listeners and raises a flag to point at an important upcoming announcement that may escape the listeners if not mentioned. Hyland's $(2005,152)$ description of these asides as expressions that "interrupt the argument to offer a comment", or a signal of an important addition for that matter (Schegloff 2003), points to the significance of locating them in utterances, as can be noted in the rendering below:

$$
\text { لكن تم التفوق على بلدنا على يد بوتين والأسد، ويالمناسبة، على يد إيران. }
$$

Following is another example (12) where the aside is positioned properly but its metadiscursive function is verbally vague:

(12) If you become president, this country is going to be in some mess. Believe me. (TPD)

$$
\text { إذا أصبحتِ رئيسة، فإن هذه البلاد ستدخل في حالة فوضى، صدقيني. }
$$

[If (you) become president, this homeland will be in a mess, believe me]

While the translator in (12) rightly maintains the placement of the personal aside at the end of the Arabic utterance, the question here is to choose one of two scenarios, which can only be resolved by observing accompanying extralinguistic gestures in an audiovisual recording. If Trump injects the aside believe me to rebuke Clinton for her mismanagement and says that in an exercise of power, then the translation صدّقتيني believe addressing (2ndP/SG/FEM) me] would be appropriate given that he maintain facing her. Yet, if his aim is to call for people's alertness to trouble they could put themselves in by electing her, then the rendering صدقوني [believe addressing (2ndP/PL/MAS \& FEM) me] would be the right choice given that Trump turn his look from Clinton to face the audience. In this way, the choice of one scenario over the other in interpreting the metacommunicative function of this personal aside depends on close observation of its audiovisual image. Trump's visual image, i.e. whether he is directing his look to Clinton as opposed to directing it to the audience, therefore, necessitates different renditions of the personal aside. 
Farghal, Kalakh

\section{Conclusion}

Based on a large corpus, this paper has examined a selected number of engaging English metadiscourse markers in an attempt to show how they function in political dialogues (namely American (vice)-presidential debates) and the way they could be appropriately rendered into Arabic. With engagement markers constituting $43.7 \%$ of the MD markers in the corpus, the key role they play in maintaining the phatic and appellative functions in political dialogues points to their importance and sensitivity in both intralingual and interlingual communication when interpreting discourse. The data analysis displays a variety of engagement markers, including (listener) pronouns, appeals to shared knowledge, directives, questions, and personal asides.

From a translational perspective, engagement markers are crucial for sustaining the communicative channel, but they often fall victim to negligence or erroneous interpretation in the flow of discourse, e.g. personal asides that interrupt speech at a certain point may be placed differently with a possible shifting of audience's attention to where they should not go. The data analysis shows that manipulating these markers usually impacts clusivity in politics, namely Wieczorek's (2013) triangle of PerspectiveDistanciation-Proximization. As translators may interfere by emplacing a voice marker, they might be jeopardizing the speech tactics enveloped in the ST, e.g. by inserting a second person pronoun that could imply an unintended relational value with the listener. In such cases, the translator would be unrightfully overtaking the role of demarcating the political distance between the candidates and the electorate. Thematically, a successful political translation should observe essential clusivity markers that are heavily present in presidential debates like ideological polarization, emphasizing self-power, legitimizing or positive-presentation of the self, and delegitimizing or negative-presentation of the other.

Not only does studying MD markers in their phrasal form enable translators to handle difficulty of their translation, but it also sensitizes them to their conventional nature in speech, a fact which adds to their subtle nature as such markers function on a level that is beyond the referential import in discourse. While inherent collocational patterns have been brought to the fore as a distinguishing feature of metadiscursive expressions in speech in general (cf. Auria 2006) and in political dialogue in particular, it remains true when translating between English and Arabic that one-to-one correspondence proves to be generally out of reach in many instances. This is due to the fact that Arabic is an inflectional language, e.g. the uniform English personal aside believe me would call for several Arabic renderings depending on the categories of number and gender of the addressee(s). Added to that, unlike English, Arabic still lacks systematic studies that produce models for MD markers, which could be a serious obstacle to translators in their endeavor to interpret and render metacommunication. 
Engagement in Translation: Interactional Metadiscourse

Markers in American Presidential Debates

\title{
التفاعل مع الجمهور في الترجمة: ما-فوق-الخطاب في نقاشات الرئاسة الأمريكية
}

\author{
محمد فرغل \\ قسم اللفة الإنجليزية، جامعة اليرموك، الأردن فرغ \\ بشرى كلخ \\ قسم اللغة الإنجليزيّة، جامعة الخليج، الكويت
}

الملخص

يرسم السياسيون خارطة للجمهور الذي يخاطبونه كي يشركونه بمستقبل موعود، مستخدمين مفردات وتراكيب من

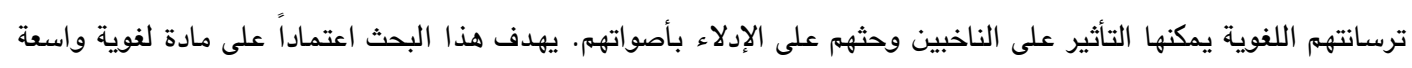

إلى تفحص عدد منتقى من التعبيرات التفاعلية بما في ذلك الضمائر، والإشارة إلى المعرفة المشتركة، والتوجيه، والسؤال،

والعبارات المعترضة، في محاولة لفهم وظيفتها كجزء أساسي من ما-فوق-الخطاب في هذه النقاشات، والنظر إلى كيفية ترجمتها إلى اللغة العربية. وتستند هذه الدراسة إلى تصنيف هايلاند (2005) لعلامات ما-فوق-الخطاب وإدارة الضمائر في الخطاب السياسي عند وزربيكا (2013)، آخذين بعين الاعتبار مفهوم ما-فوق-الخطاب في الترجمة عند نورد (2007) . وتشير النتائج إلى أن الحذف وسوء الفهم لعلامات التفاعل الدقيقة الموجهة إلى الجمهور قد تلحق ضرراً بقناة التواصل فوق-الخطابية، إذ إنها قد تغير الوجهة وتزل عن نقل الرسائل المتوخاة بشقيها العاطفي والجدلي، خاصة أن اللغة العربيّ، بعكس اللغة الإنجليزيّة،

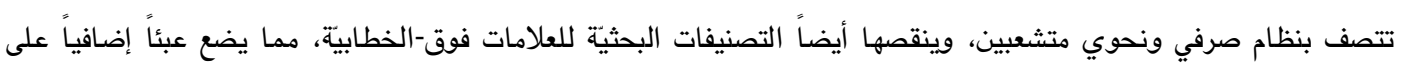
المترجم بين الإنجليزيّة والعربيّة في هذا الموضوع الدقيق.

الكلمات المفتاحية: اللغة الإنجليزية، اللغة العربية، الترجمة، ما-فوق-الخطاب، إدخال الجمهور في الخطاب، النقاشات 
Farghal, Kalakh

\section{References}

Ädel, Annelie. 2006. Metadiscourse in L1 and L2 English. Amsterdam: John Benjamins Publishing.

Ädel, Annelie. 2010. "Just to give you kind of a map of where we are going: A Taxonomy of

Metadiscourse in Spoken and Written Academic English." Nordic Journal of English Studies 9, no.

2, 69. doi:10.35360/njes.218.

Auria, Carmen. 2006. "Signaling speaker's intentions: towards a phraseology of textual metadiscourse in academic lecturing." In English as a Glo Calization Phenomenon. Observations from a Linguistic Microcosm, edited by Gibson R. Ferguson and Carmen Pérez-Llantada, 59-86. València: Universitat de València,

Bublitz, Wolfram, and Axel Hübler. 2007. "Introducing metapragmatics in use." In Metapragmatics in Use. Amsterdam: John Benjamins Publishing.

Chafe, Wallace. 1982. "Integration and involvement in speaking, writing and oral literature." In Spoken and Written Language: Exploring Orality and Literacy, edited by Deborah Tannen, 35-53. New York: Ablex Publishing Corporation.

Chilton, Paul A., and Christina Schäffner. 2002. "Introduction: Themes and principles in the analysis of political discourse." In Politics as Text and Talk: Analytic Approaches to Political Discourse. Amsterdam: John Benjamins Publishing.

Fairclough, Norman. Critical Discourse Analysis: The Critical Study of Language. London: Longman, 1995.

Farghal, Mohammad. 2017. "Textual issues relating to cohesion and coherence in Arabic/ English translation." Journal of Modern Languages and Literature 9, no. 1, 29-50.

Greenbaum, Sidney. 1990. A Student's Grammar of the English Language. Harlow: Longman Publishing Group.

Holmes, James. "The name and nature of translation studies. In Third international congress of applied linguistics (Copenhagen, 21-26 August 1972): Congress Abstracts, Copenhagen:

Ehrverskokonomisk Forlag, edited by J. Qvistgaard, H. Schwarz, and H. Spang-Hanssen, 66-80. Retrieved from https://eric.ed.gov/PDFS/ED074796.pdf

Hyland, Ken.2005. Metadiscourse: Exploring Interaction in Writing. London: Continuum, Conference session.

Hyland, Ken. 2015. "Metadiscourse." In The International Encyclopedia of Language and Social Interaction, 3 Volume Set, edited by Karen Tracy, Cornelia Ilie, and Todd Sandel, 1st ed., 1-11. Hoboken: John Wiley \& Sons, doi:10.1002/9781118611463/wbielsi003.

Hyland, Ken, and Polly Tse. 2004. "Metadiscourse in Academic Writing: A Reappraisal." Applied Linguistics 25, no. 2. 156-177. doi:10.1093/applin/25.2.156.

Jakobson, Roman, Linda R. Waugh, and Roman Jakobson. 1985. "Metalanguage as a linguistic problem." In Selected Writings: VII, Contributions to comparative mythology. Studies in linguistics an philology, 113-121. Berlin: De Gruyter Mouton. 
Engagement in Translation: Interactional Metadiscourse Markers in American Presidential Debates

Kintsch, Walter. 1998. Comprehension: A Paradigm for Cognition. Cambridge: Cambridge University Press.

Latawiec, Beata. 2012. "Metadiscourse in oral discussions and persuasive essays of children exposed to collaborative reasoning." PhD diss., Illinois. https://www.ideals.illinois.edu/handle/2142/42302.

Leech, Geoffrey N. 2016. Principles of Pragmatics. London: Routledge.

Mauranen, Anna. 2010. "Discourse Reflexivity - A Discourse Universal? The Case of ELF. " Nordic Journal of English Studies 9, no. 2, 13. doi:10.35360/njes.216.

Nord, Christiane. 1997. "Defining translation functions. The translation brief as a guideline for the trainee translator." Ilha Do Desterro 33, 41-55. http://dx.doi.org/10.5007/\%25x.

Nord, Christiane. 2016. "Meaning, Sense, Function - What is Transferred?" Procedia - Social and Behavioral Sciences 231, 3-10. doi:10.1016/j.sbspro.2016.09.064.

Nord, Christiane. 2017. "The Phatic Function in Translation: Metacommunication as a Case in Point." The Study of Language and Translation 21, 171-184. doi:10.1075/bj1.21.12nor.

Okulska, Urszula, Piotr Cap, and Christina Schäffner. 2010. "Political communication: Mediated by translation." In Perspectives in Politics and Discourse, 255-278. Amsterdam: John Benjamins Publishing.

Schegloff, Emanuel. 2008. "Discourse as an interactional achievement III: The omnirelevance of action." In The Handbook of Discourse Analysis, edited by Deborah Schiffrin, Deborah Tannen, and Heidi E. Hamilton, 229-249. Oxford: Blackwell Publisher.

Schäffner, Christina. 2012. "Unknown agents in translated political discourse." Target. International Journal of Translation Studies 24, no. 1, 103-125. doi:10.1075/target.24.1.07sch.

Sultan, Abbas. 2011. "A contrastive study of metadiscourse in English and Arabic linguistics research articles." ACTA LINGUISTICA 5, no. 1, 28-41. http://www.actalinguistica.com/arhiv/index.php/als/article/viewFile/354/485

Van Dijk, Teun A. 1997. "What is Political Discourse Analysis?" Political Linguistics 11, 11-52. doi:10.1075/bjl.11.03dij.

Wieczorek, Anna E. 2013. Clusivity: A New Approach to Association and Dissociation in Political Discourse. Newcastle upon Tyne: Cambridge.

\section{Appendix}

\section{List of Arabic Phonetic Symbols}

/b/ voiced bilabial stop

$/ \mathrm{m} /$ bilabial nasal stop

/f/ voiceless labio-dental fricative

/ð/ voiced interdental fricative

/ / voiced interdental emphatic fricative 
Farghal, Kalakh

$/ \theta /$ voiceless interdental fricative

/d/ voiced alveolar stop

/t/ voiceless alveolar stop

/ḍ/ voiced alveolar emphatic stop

/ț/ voiceless alveolar emphatic stop

/z/ voiced alveolar fricative

/s/ voiceless alveolar fricative

/ș/ voiceless alveolar emphatic fricative

/n/ alveolar nasal stop

/r/ alveolar trill liquid

/l/ alveolar lateral liquid

/š/ voiceless alveo-palatal fricative

/j/ voiced palatal affricate

/y/ palatal glide

/w/ labio-velar glide

/g/ voiced velar stop

/k/ voiceless velar stop

$/ \gamma /$ voiced uvular/post-velar fricative

/x/ voiceless uvular/post-velar fricative

/q/ voiceless uvular stop

/\%/ voiced pharyngeal fricative

/h/ voiceless pharyngeal fricative

I'/ glottal stop

/h/ voiceless laryngeal fricative

/i/ high front short vowel

/u/ high back short vowel

/a/ low half-open front-to-centralized short vowel

/ii/ high front long vowel

/uu/ high back long vowel

/aa/ low open front-to-centralized long vowel

/ee/ mid front long vowel

/oo/ mid back long vowel. 